\title{
PELATIHAN BIDAN TENTANG KOMUNIKASI INTERPERSONAL DAN KONSELING (KIP/K) DALAM UPAYA PENINGKATAN KUALITAS ANTENATAL CARE DI PUSKESMAS KALITIDU KABUPATEN BOJONEGORO
}

\author{
Siti Mar'atus Sholikah" ${ }^{1 *}$, Sri Anggraeni ${ }^{2}$, Ari Tri Rahayu ${ }^{3}$ \\ ${ }^{1-3}$ Prodi D3 Kebidanan Bojonegoro Poltekkes Kemenkes Surabaya \\ Email Korespondensi: smsholikah@gmail.com
}

Disubmit: 14 Oktober $2021 \quad$ Diterima: 23 Desember $2021 \quad$ Diterbitkan: 02 Januari 2022 DOI: https://doi.org/10.33024/jkpm.v1i1.5309

\begin{abstract}
ABSTRAK
Indikator keteraturan pemeriksaan kehamilan menggambarkan kualitas pelayanan Program Kesehatan Ibu dan Anak (KIA). Pada tahun 2019 di Puskesmas Kalitidu cakupan Kunjungan Kehamilan (K4) di Puskesmas Kalitidu belum mencapai target $100 \%$ yaitu tercapai $91 \%$. Komplikasi kehamilan targetnya 15 20\%, tercapai 40.96\% dan komplikasi persalinan 44,17\%. Angka Kematian Bayi (AKB) sebesar 8,13/1000 KH. Sedangkan Bidan di wilayah Puskesmas Kalitidu yang belum mengikuti pelatihan KIP/K sebesar 20 orang $(90,91 \%)$ dari 22 bidan.Tujuan umum untuk meningkatkan pengetahuan dan keterampilan Bidan melalui pelatihan bidan tentang Komunikasi Interpersonal dan Konseling (KIP/K) dalam upaya peningkatan kualitas ANC. Pelatihan ini dilaksanakan selama tiga hari di Puskesmas Kalitidu, diikuti 22 bidan dengan metode ceramah tanya jawab, demonstrasi dan praktik KIP/K. Hasil kegiatan adalah peningkatan kualitas Bidan dalam KIP/K yaitu peningkatan pengetahuan dengan nilai rata-rata post tes $94,55 \%$, keterampilan KIP/K nilai rata-rata $82,50 \%$, terbentuknya Komitmen Bersama Bidan dalam mendukung mensukseskan kegiatan Bidan tentang KIP\&K dalam upaya peningkatan kualitas ANC. Luarannya peningkatan kualitas Bidan, HKI, Modul dan jurnal. Saran: sosialisasi KIP/K pada Bidan yang belum mengikuti pelatihan dan 7 hak ibu hamil pada pelayanan ANC serta menerapkannya dalam pelayanan $A N C$.
\end{abstract}

Kata kunci: Bidan, KIP/K, Pengabmas, pelatihan.

\section{ABSTRACT}

The indicators of regularity for antenatal care describe the quality of services for the Maternal and Child Health Program (MCH). In 2019 at the Kalitidu Health Center cThe coverage of Pregnancy Visits (K4) at the Kalitidu Health Center has not reached the $100 \%$ target, which is $91 \%$. The target for pregnancy complications is $15-20 \%$, achieved $40.96 \%$ and delivery complications $44.17 \%$. The Infant Mortality Rate (IMR) is $8.13 / 1000 \mathrm{KH}$. Meanwhile, 20 midwives in the Kalitidu Community Health Center have not attended KIP/K training (90.91\%) out of 22 midwives. ANC quality. This training was held for three days at the Kalitidu Health Center, attended by 22 midwives with a question and answer lecture method, demonstration and KIP/K practice. The result of the activity is an increase in the quality of Midwives in KIP/K, namely an increase in knowledge with an average post-test score of $94.55 \%$, KIP/K skills an average score of 
$82.50 \%$, the formation of a Joint Commitment of Midwives in supporting the success of Midwives' activities on KIP\&K in an effort to improve the quality of ANC. The output is improving the quality of midwives, HKI, modules and journals. Suggestion: socialization of KIPIK to midwives who have not attended training and 7 rights of pregnant women in ANC services and apply them in ANC services.

Keywords: Midwife, KIP/K, Community Service, training.

\section{PENDAHULUAN}

Kesehatan ibu dan anak (KIA) merupakan salah satu perhatian dari World Health Organization (WHO) karena ibu merupakan komponen penting dalam pembangunan setiap bangsa untuk mempersiapkan generasi yang berkualitas di masa yang akan dating (Handajani, 2016). Penilaian terhadap status kesehatan dan kinerja upaya kesehatan penting dilakukan, salah satu indikatornya adalah Angka Kematian Ibu (AKI) (Kemenkes RI, 2014).

Di Kabupaten Bojonegoro terdapat 36 Puskesmas, cakupan indikator pelayanan KIA dalam tiga tahun terakhir memperlihatkan kinerja KIA di Dinas Kesehatan Kabupaten Bojonegoro masih rendah dimana Angka Kematian Ibu (AKI) trendnya meningkat, pada tahun 2017 AKI 96,64/100.000 Kelahiran Hidup (KH), tahun 2018 AKI 157,23/100.000 KH dan pada tahun 2019 AKI 149,66/100.000 KH. Penyebab AKI di Bojonegoro tahun 2019 adalah Pre Eklampsia/Eklampsia 30,77\%, perdarahan 30,77\%, Infeksi 3,85\%, Jantung 7,69\% dan penyakit penyerta 26,92\%. Angka Kematian Bayi (AKB) trendnya meningkat, dimana pada tahun 2017 AKB 8,76/1000 Kelahiran Hidup (KH), tahun 2018 AKB 9,78/1000 KH dan pada tahun 2019 AKB 9,27/1000 KH. Penyebab terbesar AKB adalah Berat Badan Lahir Rendah (BBLR) 39,9\%, Asfiksia 14,6\%, dan kelainan kongenital 12,7\% (Kabupaten Bojonegoro, 2017, 2018, 2019) Cakupan Kunjungan Kehamilan (K4) di Puskesmas Kalitidu belum mencapai Standar Pelayanan Minimal 100\%, dimana K4 pada tahun 2018 pencapaianya 82.5\% dan pada tahun 2019 tercapai 91\%. Komplikasi kehamilan di Puskesmas Kalitidu pada tahun 2018 adalah 39,19\% dan komplikasi persalinan 32,26\% dari targetnya 15-20\%, pada tahun 2019 komplikasi kehamilan 40.96\% dan komplikasi persalinan 44,17\%. Angka Kematian Bayi (AKB) tahun 2019 sebesar 8,13/1000 KH (Pantiawati, 2010). Bidan di wilayah Puskesmas Kalitidu ada 22 orang, bidan yang belum mengikuti pelatihan KIP/K sebesar 20 orang (90,91\%) (Puskesmas Kalitidu, 2018, 2019)

Melihat keadaan demikian, berbagai pihak terkait yakni dari sektor kesehatan bersama dengan sektor non kesehatan melalui berbagai kegiatan untuk mempercepat penurunan AKI dan AKB, salah satunya melakukan kegiatan Komuniaksi Informasi dan Edukasi disetiap pelayanan kesehatan ibu dan bayi baru lahir dalam rangka mewujudkan pelayanan kesehatan ibu dan bayi baru lahir yang berkualitas, dimana tenaga kesehatan (bidan) harus mempunyai kemampuan melakukan pelayanan kesehatan secara profesional di bidang teknis kebidanan dan kemampuan berkomunikasi dalam hal ini komunikasi interpersonal dan konseling (KIP/K). Mengacu kepada butir analisa permasalahan yang teridentifikasi maka ditemukan dua masalah utama yang dihadapi mitra yaitu belum maksimalnya kualitas pelayanan ANC dan belum maksimalnya bidan dalam Diklat, khususnya pelatihan Komunikasi Interpersonal dan Konseling (KIP/K) (Sulistiyanti \& Sunarti, 2015)

Tujuan umum pengabdian masyarakat ini meningkatkan pengetahuan dan keterampilan bidan melalui pelatihan bidan tentang Komunikasi Interpersonal 
dan Konseling (KIP/K) dalam upaya peningkatan kualitas Antenatal Care di wilayah puskesmas Kalitidu Kabupaten Bojonegoro

\section{MASALAH}

Cakupan Kunjungan Kehamilan (K4) di Puskesmas Kalitidu belum mencapai Standar Pelayanan Minimal 100\%, dimana K4 pada tahun 2018 pencapaianya $82.5 \%$ dan pada tahun 2019 tercapai $91 \%$. Komplikasi kehamilan di Puskesmas Kalitidu pada tahun 2018 adalah 39,19\% dan komplikasi persalinan 32,26\% dari targetnya 15-20\%, pada tahun 2019 komplikasi kehamilan $40.96 \%$ dan komplikasi persalinan 44,17\%. Angka Kematian Bayi (AKB) tahun 2019 sebesar $8,13 / 1000 \mathrm{KH}$. Bidan di wilayah Puskesmas Kalitidu ada 22 orang, bidan yang belum mengikuti pelatihan KIP/K sebesar 20 orang $(90,91 \%)$.

Gambar 2.1 Peta Lokasi Kegiatan Pengabdian Kepada Masyarakat

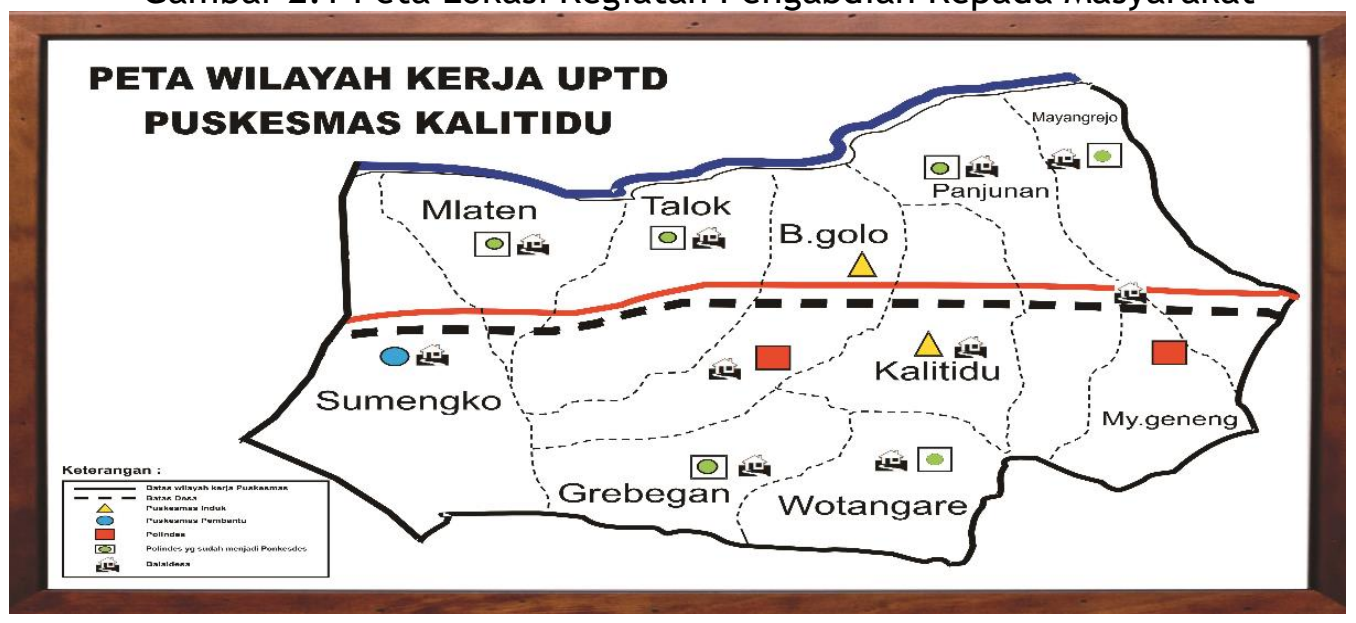

\section{METODE}

Metode yang digunakan dalam kegiatan Pelatihan Bidan tentang Komunikasi Interpersonal dan Konseling (KIP/K) dalam upaya peningkatan kualitas Antenatal Care adalah Ceramah Tanya Jawab, demonstrasi, praktek KIP/K, pre test dan post test tentang KIP/K (Febriati \& Novika, 2021; Sunarni et al., 2016) Pelatihan dilaksanakan secara luring selama 3 hari dan kegiatan maksimal 4 jam dan melaksanakan sesuai protokol kesehatan

\subsection{Tahap Persiapan}

Kegiatan diawali dengan pembuatan proposal pada bulan Juli 2020 dan pengumuman diterimanya proposal pada Agustus 2020. Kemudian penandatanganan kontrak pengabdian masyarakat antara ketua pelaksana dengan Direktur Poltekkes Kemenkes Surabaya. Dilanjutkan pengurusan ijin ke :

a. Dinas Penanaman Modal dan Pelayanan Terpadu Satu Pintu Kabupaten Bojonegoro

b. Dinas Kesehatan Kabupaten Bojonegoro dengan Tembusan Puskesmas Kalitidu

\subsection{Tahap Pelaksanaan}

Tempat pelaksanaan pelatihan di Ruang Pertemuan Puskesmas Kalitidu Kabupaten Bojonegoro, Waktu pelaksanaan adalah 22 September s/d 24 September 2021. Jumlah peserta 22 Bidan yang ada di wilayah Puskesmas Kaitidu Bojonegoro. Tim Pengabdian masyarakat dibantu Bidan Koordinator dan Kepala 
Puskesmas Kalitidu dengan memberikan undangan kepada peserta pelatihan. Pelaksanaan pelatihan diawali acara pembukaan, dilanjutkan Pre Test dan pemberian materi oleh narasumber, demonstrasi KIP/K dalam pelayanan ANC. Pemberian materi selesai pada hari ke 3 (tiga), dilanjutkan posttest dan penandatangan Pakta Integritas, Komitmen Bersama dalam mendukung mensukseskan kegiatan Bidan tentang Komunikasi Interpersonal dan Konseling (KIP/K) dalam upaya peningkatan kualitas ANC di

Wilayah Puskesmas Kalitidu Kabupaten Bojonegoro serta diakhiri acara penutupan oleh Kepala Puskesmas Kalitidu Bojonegoro.

\subsection{Evaluasi Pelaksanaan}

Peserta pelatihan hadir sebanyak 22 orang. Setting tempat sudah sesuai dengan rencana yang dibuat dan perlengkapan yang dibutuhan untuk acara pelatihan telah tersedia dan sudah digunakan sebagaimana mestinya. Penggunaan Bahasa yang digunakan komunikatif dan peserta pelatihan mengikuti kegiatan mulai hari pertama sampai terakhir jumlahnya lengkap, disiplin dan antusias.

\section{HASIL DAN PEMBAHASAN}

Hasil Pengabdian Masyarakat "Pelatihan Bidan Tentang Komunikasi Interpersonal atau Konseling (KIP/K) menurut(Febriati \& Novika, 2021) (Handajani, 2016)

\subsection{Pengetahuan Peserta}

Evaluasi pengetahuan peserta menggunakan pre test dan post test.

Tabel 4.1 Nilai Pre Test Dan Post Test Pengetahuan Pelatihan Bidan tentang Komunikasi Interpersonal dan Konseling (KIP/K) dalam upaya peningkatan kualitas Antenatal Care di wilayah Puskesmas Kalitidu Kabupaten Bojonegoro , September 2021

\begin{tabular}{ccccc} 
No & Uraian & Pre Test & Post Test & $\begin{array}{c}\text { Keteranga } \\
\mathrm{n}\end{array}$ \\
\hline 1 & Nilai Terendah & 32 & 80 & Meningkat \\
2 & Nilai Tertinggi & 72 & 96 & Meningkat \\
\hline & Nilai Rata-Rata & 51,82 & 94,55 & Meningkat \\
\hline
\end{tabular}

Tabel 4.2 Nilai Post Test Pengetahuan Pelatihan Bidan tentang Komunikasi Interpersonal dan Konseling (KIP/K) dalam upaya peningkatan kualitas Antenatal Care di wilayah Puskesmas Kalitidu Kabupaten Bojonegoro , September 2021

\begin{tabular}{clcr}
\hline No & \multicolumn{1}{c}{ Kategori } & Frekuensi (orang) & \multicolumn{1}{c}{$\%$} \\
\hline 1 & Sangat Baik (79-100) & 22 & 100,00 \\
2 & Baik (68-78) & 0 & 0,00 \\
3 & Cukup (55-67) & 0 & 0,00 \\
\hline & Jumlah & 22 & 100,00
\end{tabular}




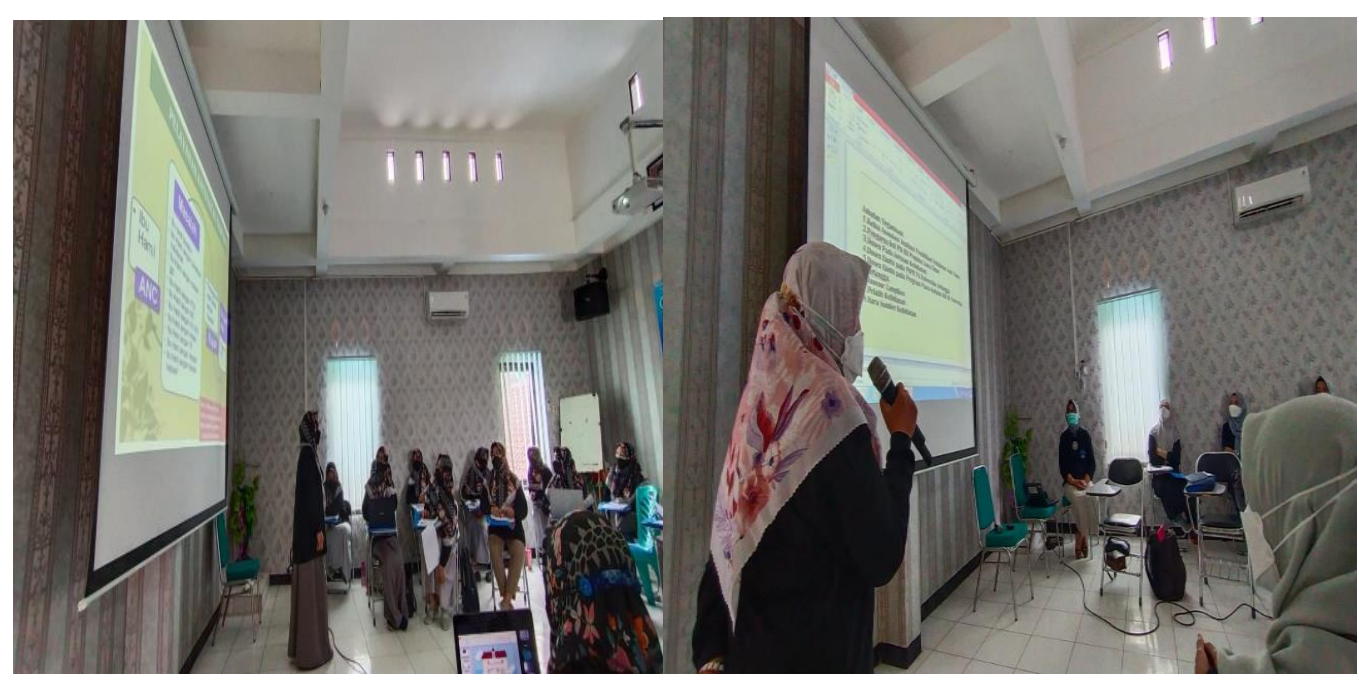

\subsection{Keterampilan KIP/K}

Penilaian keterampilan KIP/K melalui penilaian praktik pada ibu hamil.

Tabel 4.3 Nilai Terendah, Tertinggi, Dan Rata-Rata Keterampilan Bidan tentang Komunikasi Interpersonal dan Konseling (KIP/K) dalam upaya peningkatan kualitas Antenatal Care di wilayah Puskesmas Kalitidu Kabupaten Bojonegoro, September 2021

\begin{tabular}{ccc} 
No & Uraian & Nilai \\
\hline 1 & Nilai Terendah & 75 \\
2 & Nilai Tertinggi & 90 \\
\hline & Nilai Rata-Rata & 82,50 \\
\hline
\end{tabular}

Tabel 4.4 Kategori Nilai Keterampilan Bidan tentang Komunikasi Interpersonal dan Konseling (KIP/K) dalam upaya peningkatan kualitas Antenatal Care di wilayah Puskesmas Kalitidu Kabupaten Bojonegoro , September 2021

\begin{tabular}{llcr}
\hline No & Kategori & $\begin{array}{c}\text { Frekuensi } \\
\text { (orang) }\end{array}$ & $\%$ \\
\hline 1 & Sangat Baik (79-100) & 19 & 86,36 \\
2 & Baik (68-78) & 3 & 13,64 \\
3 & Cukup (55-67) & 0 & 0,00 \\
\hline \multicolumn{2}{c}{ Jumlah } & 22 & 100,00 \\
\hline
\end{tabular}

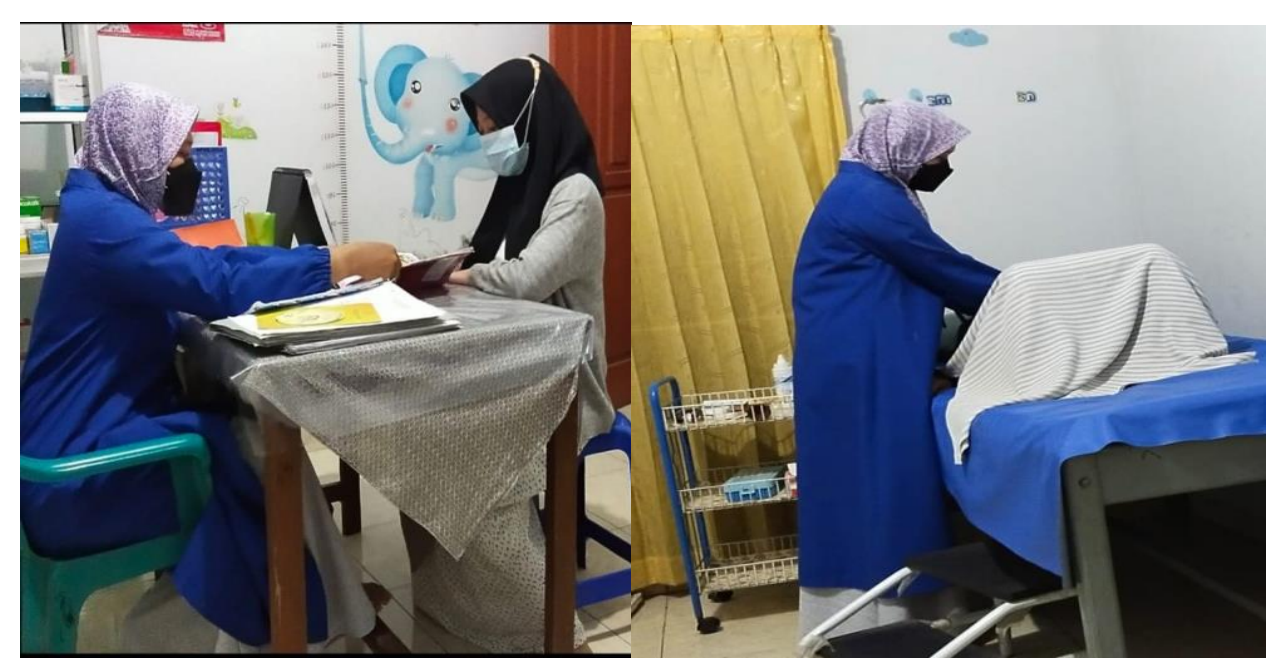




\subsection{Komitmen Bersama Mendukung dan Mensukseskan Kegiatan Bidan} tentang Komunikasi Interpersonal dan Konseling (KIP/K) dalam upaya peningkatan kualitas ANC

Pelatihan ini menghasilkan Komitmen Bersama dalam mendukung mensukseskan kegiatan Bidan tentang Komunikasi Interpersonal dan Konseling (KIP/K) dalam upaya peningkatan kualitas ANC Wilayah Puskesmas Kalitidu Kabupaten Bojonegoro, bulan September 2021 di Kabupaten Bojonegoro. Komitmen bersama ini ditandatangani oleh seluruh peserta pelatihan yang terdiri 22 Bidan Puskesmas Kalitidu.

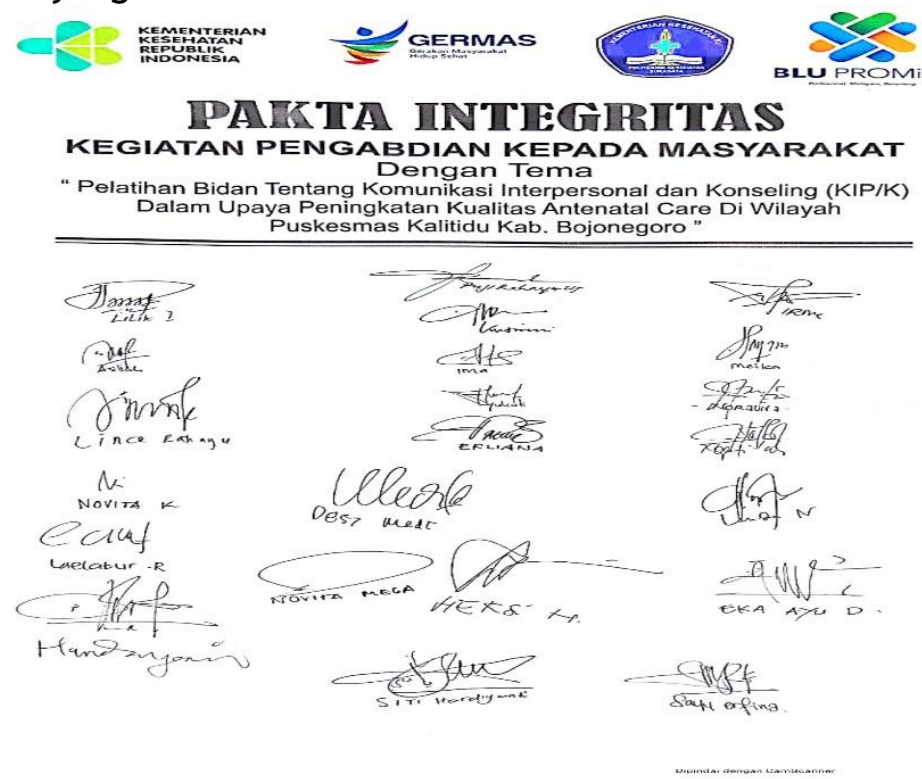

\subsection{Monitoring dan Evaluasi}

Monitoring dan evaluasi sebagai tindak lanjut pelatihan ini dilaksanakan pada tangggal 1 Oktober 2021 oleh Tim Pengabmas dengan menggunakan 2 metoda yaitu Metoda Penilaian diri sendiri oleh Bidan dan Metoda Penilaian Bidan peserta pelatihan oleh 5 Ibu Hamil terhadap KIP \& K dalam pelayanan ANC.

Berikut ini adalah laporan kegiatan monitoring dan evaluasi setelah pelatihan Komunikasi Interpersonal dan Konseling:

1). Metoda Penilaian Diri sendiri

Metoda penilaian diri sendiri oleh Bidan, dengan tujuan ingin mengetahui sejauh mana ia telah memiliki kemampuan Komunikasi Interpersonal dan Konseling dasar dengan mengisi daftar tilik tentang empat area kompetensi KIP \& K:

a). Penilaian Diri oleh Bidan dalam Kemampuan Komunikasi Interpersonal dan Konseling Pada Pelayanan Antenatal Care Terhadap Pemantapan Hubungan Baik

Penilaian Diri oleh Bidan dalam Kemampuan Komunikasi Interpersonal dan Konseling Pada Pelayanan Antenatal Care Terhadap Pemantapan Hubungan Baik seperti tercantum pada Tabel 4.5 di bawah ini.

Tabel 4.5 Gambaran Penilaian Diri oleh Bidan dalam Kemampuan Komunikasi Interpersonal dan Konseling Pada Pelayanan Antenatal Care Terhadap Pemantapan Hubungan Baik di Wilayah Puskesmas Kalitidu Kabupaten Bojonegoro, September 2021 


\begin{tabular}{|c|c|c|c|}
\hline \multirow[t]{2}{*}{ No } & \multirow[t]{2}{*}{ Area Kompetensi oleh Bidan } & \multicolumn{2}{|c|}{$\begin{array}{c}\text { Penilaian Diri oleh } \\
\text { Bidan Di Puskesmas } \\
\text { Kalitidu } \\
n=22\end{array}$} \\
\hline & & $\begin{array}{c}\text { Ya } \\
\text { (Frek) }\end{array}$ & $\%$ \\
\hline I & PEMANTAPAN HUBUNGAN BAIK & & \\
\hline 1 & $\begin{array}{l}\text { Kemampuan menciptakan lingkungan } \\
\text { yang nyaman dan bersifat pribadi selama } \\
\text { melakukan KIP\&K }\end{array}$ & 19 & 86,36 \\
\hline 2 & $\begin{array}{l}\text { Kemampuan Menyambut baik klien } \\
\text { dengan salam dan senyum }\end{array}$ & 22 & 100,00 \\
\hline 3. & $\begin{array}{l}\text { Kemampuan melakukan kontak mata } \\
\text { dengan klien secara wajar }\end{array}$ & 16 & 72,73 \\
\hline 4 & $\begin{array}{l}\text { Kemampuan memberikan ekspresi wajah } \\
\text { yang menunjukkan perhatian, minat dan } \\
\text { penerimaan }\end{array}$ & 19 & 86,36 \\
\hline 5 & $\begin{array}{l}\text { Kemampuan menilai tanda-tanda non } \\
\text { verbal klien }\end{array}$ & 16 & 72,73 \\
\hline 6 & $\begin{array}{l}\text { Kemampuan menilai tanda-tanda verbal } \\
\text { klien }\end{array}$ & 22 & 100,00 \\
\hline 7. & $\begin{array}{l}\text { Kemampuan untuk menyampaikan } \\
\text { ucapan yang menunjukkan perhatian, } \\
\text { minat dan penerimaan serta } \\
\text { keterlibatannya dengan permasalahan } \\
\text { yang sedang dihadapi oleh kliennya }\end{array}$ & 22 & 100,00 \\
\hline 8. & $\begin{array}{l}\text { Kemampuan untuk mengatasi kemacetan } \\
\text { pembicaraan secara tepat }\end{array}$ & 16 & 72,73 \\
\hline 9. & $\begin{array}{l}\text { Kemampuan untuk menjaga kerahasian } \\
\text { pasien }\end{array}$ & 22 & 100,00 \\
\hline 10. & $\begin{array}{l}\text { Kemampuan untuk menjaga serta } \\
\text { memberikan pelayanan yang bersifat } \\
\text { privasi, yakni ada rasa aman, adanya } \\
\text { kedekatan, keterbukaan sangat } \\
\text { membantu terjadinya KIPK yang } \\
\text { bersahabat }\end{array}$ & 22 & 100,00 \\
\hline 11. & $\begin{array}{l}\text { Kemampuan untuk menciptakan tempat } \\
\text { pemeriksaan yang bersifat privasi yakni } \\
\text { dengan menggunakan ruangan khusus, } \\
\text { menutup tirai atau pintu, mengatur meja } \\
\text { ginekolog agar bagaian bawah tubuh } \\
\text { klien tidak menghadap ke pintu }\end{array}$ & 22 & 100,00 \\
\hline \multirow[t]{2}{*}{12} & $\begin{array}{l}\text { Kemampuan memperlakukan klien dan } \\
\text { keluarganya secara terhormat }\end{array}$ & 22 & 100,00 \\
\hline & Rata-Rata Pemantapan Hubungan Baik & & 90,91 \\
\hline
\end{tabular}

Keterangan : Nilai baik (>80\%), cukup (64\%-80\%), kurang (<64\%) 
Berdasarkan Tabel 4.5 tersebut di atas dapat diketahui bahwa Evaluasi dengan metoda penilaian diri oleh Bidan dalam Komunikasi Interpersonal dan Konseling dalam Pelayanan Antenatal Care pada Pemantauan Hubungan baik rata-rata di Puskesmas Kalitidu Kab. Bojonegoro adalah baik (rata-rata 90,91\%).

b). Penilaian Diri oleh Bidan dalam Kemampuan Komunikasi Interpersonal dan Konseling Pada Pelayanan Antenatal Care Terhadap Pengumpulan dan Pemberian Informasi

Penilaian Diri oleh Bidan dalam Kemampuan Komunikasi Interpersonal dan Konseling Pada Pelayanan Antenatal Care Terhadap Pengumpulan dan Pemberian Informasi seperti tercantum pada Tabel 4.6 di bawah ini.

Tabel 4.6 Gambaran Penilaian Diri oleh Bidan dalam Kemampuan Komunikasi Interpersonal dan Konseling Pada Pelayanan Antenatal Care Terhadap Pengumpulan dan Pemberian Informasi di Wilayah Puskesmas Kalitidu Kabupaten Bojonegoro, September 2021

\begin{tabular}{|c|c|c|c|}
\hline \multirow[t]{2}{*}{ No } & \multirow[t]{2}{*}{ Area Kompetensi oleh Bidan } & \multicolumn{2}{|c|}{$\begin{array}{l}\text { Penilaian Diri oleh } \\
\text { Bidan Di Puskesmas } \\
\text { Kalitidu } \\
n=22\end{array}$} \\
\hline & & $\begin{array}{c}\text { Ya } \\
\text { (Frek) }\end{array}$ & $\%$ \\
\hline II & $\begin{array}{l}\text { PENGUMPULAN DAN PEMBERIAN } \\
\text { INFORMASI }\end{array}$ & & \\
\hline 1. & $\begin{array}{l}\text { Kemampuan menanyakan alasan } \\
\text { kunjungan klien }\end{array}$ & 13 & 59,09 \\
\hline 2 & $\begin{array}{l}\text { Kemampuan untuk mengajukan secara } \\
\text { satu persatu }\end{array}$ & 16 & 72,73 \\
\hline 3 & $\begin{array}{l}\text { Kemampuan untuk tidak menggunakan } \\
\text { pertanyaan tertutup atau mengarah }\end{array}$ & 13 & 59,09 \\
\hline 4 & $\begin{array}{l}\text { Kemampuan menanggapi dengan serius } \\
\text { keprihatianan klien }\end{array}$ & 16 & 72,73 \\
\hline 5 & $\begin{array}{l}\text { Kemampuan menjadi pendengar yang } \\
\text { baik/yang aktif, yakni mendengarkan } \\
\text { keluhan dan ungkapan klien, tidak } \\
\text { memotong pembicaraan klien }\end{array}$ & 19 & 86,36 \\
\hline 6. & $\begin{array}{l}\text { Kemampuan member kesan kepada klien, } \\
\text { bahwa bidan sedang mendengar dan } \\
\text { mencoba memahami apa yang } \\
\text { diungkapkan oleh klien }\end{array}$ & 22 & 100,00 \\
\hline 7. & $\begin{array}{l}\text { Kemampuan bertanya secara efektif dan } \\
\text { sopan }\end{array}$ & 22 & 100,00 \\
\hline 8. & $\begin{array}{l}\text { Kemampuan mengenali dan memberikan } \\
\text { informasi yang dibutuhkan klien }\end{array}$ & 22 & 100,00 \\
\hline 9. & $\begin{array}{l}\text { Kemampuan menidentifikasi masalah } \\
\text { yang dihadapi klien serta memberikan } \\
\text { beberapa alternatif upaya } \\
\text { pemecahannya }\end{array}$ & 16 & 72,73 \\
\hline 10 & $\begin{array}{l}\text { Kemampuan membuat klien bertanya, } \\
\text { berbicara dan mengeluarkan } \\
\text { pendapatnya }\end{array}$ & 13 & 59,09 \\
\hline
\end{tabular}




\begin{tabular}{|c|c|c|c|}
\hline \multirow[t]{2}{*}{ No } & \multirow[t]{2}{*}{ Area Kompetensi oleh Bidan } & \multicolumn{2}{|c|}{$\begin{array}{c}\text { Penilaian Diri oleh } \\
\text { Bidan Di Puskesmas } \\
\text { Kalitidu } \\
n=22\end{array}$} \\
\hline & & $\begin{array}{c}\text { Ya } \\
\text { (Frek) }\end{array}$ & $\%$ \\
\hline 11 & $\begin{array}{l}\text { Kemampuan memberikan penjelasan } \\
\text { secara singkat, lengkap dan mudah } \\
\text { dimengerti oleh klien }\end{array}$ & 22 & 100,00 \\
\hline 12 & $\begin{array}{l}\text { Kemampuan mengulangi informasi } \\
\text { penting yang harus diketahui atau } \\
\text { dilakukan oleh klien }\end{array}$ & 22 & 100,00 \\
\hline 13 & $\begin{array}{l}\text { Kemampuan menyampaikan informasi } \\
\text { dengan menggunakan istilah umum dan } \\
\text { sederhana, serta tidak menggunakan } \\
\text { bahasa medis yang tidak dimengerti oleh } \\
\text { klien }\end{array}$ & 22 & 100,00 \\
\hline 14 & $\begin{array}{l}\text { Kemampuan melakukan komunikasi non } \\
\text { verbal, misalnya mengangguk }\end{array}$ & 22 & 100,00 \\
\hline 15 & $\begin{array}{l}\text { Kemampuan mengatasi } \\
\text { kesalahpengertian serta mampu } \\
\text { mengendalikan rumor }\end{array}$ & 13 & 59,09 \\
\hline 16 & $\begin{array}{l}\text { Kemampuan melakukan rujukan apabila } \\
\text { klien membutuhkan informasi yang lebih } \\
\text { mendalam }\end{array}$ & 22 & 100,00 \\
\hline 17 & $\begin{array}{l}\text { Kemampuan menguasai tentang masalah } \\
\text { kesehatan ibu dan bayi baru lahir, } \\
\text { termasuk masalah yang terkait dengan } \\
\text { aspek sosial budaya dan kepercayaan } \\
\text { masyarakat setempat }\end{array}$ & 22 & 100,00 \\
\hline \multirow[t]{2}{*}{18} & $\begin{array}{l}\text { Kemampuan mempersiapkan serta } \\
\text { menggunakan media KIP\&K dengan benar }\end{array}$ & 22 & 100,00 \\
\hline & $\begin{array}{l}\text { Rata-Rata Pengumpulan dan Pemberian } \\
\text { Informasi }\end{array}$ & & 85,61 \\
\hline
\end{tabular}

Berdasarkan Tabel 4.6 tersebut di atas dapat diketahui bahwa Evaluasi dengan metoda penilaian diri oleh Bidan dalam Komunikasi Interpersonal dan Konseling dalam Pelayanan Antenatal Care pada Pengumpulan dan Pemberian Informasi rata-rata di Puskesmas Kalitidu Kab. Bojonegoro adalah baik (rata-rata $85,61 \%)$.

c). Penilaian Diri oleh Bidan dalam Kemampuan Komunikasi Interpersonal dan Konseling Pada Pelayanan Antenatal Care Terhadap Perencanaan, Pengambilan Keputusan, Penyelesaiaan Masalah

Penilaian Diri oleh Bidan dalam Kemampuan Komunikasi Interpersonal dan Konseling Pada Pelayanan Antenatal Care Terhadap Perencanaan, Pengambilan Keputusan, Penyelesaiaan Masalah seperti tercantum pada Tabel 4.7 di bawah ini. 
Tabel 4.7 Gambaran Penilaian Diri oleh Bidan dalam Kemampuan Komunikasi Interpersonal dan Konseling Pada Pelayanan Antenatal Care Terhadap Perencanaan, Pengambilan Keputusan, Penyelesaiaan Masalah di Wilayah Puskesmas Kalitidu Kabupaten Bojonegoro, September 2021

\begin{tabular}{|c|c|c|c|}
\hline \multirow[t]{2}{*}{ No } & \multirow[t]{2}{*}{ Area Kompetensi oleh Bidan } & \multicolumn{2}{|c|}{$\begin{array}{l}\text { Penilaian Diri oleh Bidan } \\
\text { Di Puskesmas Kalitidu } \\
\qquad n=22\end{array}$} \\
\hline & & $\begin{array}{c}\text { Ya } \\
\text { (Frek) }\end{array}$ & $\%$ \\
\hline III & $\begin{array}{l}\text { PERENCANAAN, PENGAMBILAN } \\
\text { KEPUTUSAN PENYELESAIAN MASALAH }\end{array}$ & & \\
\hline 1. & Kemampuan menghormati hak-hak klien & 22 & 100,00 \\
\hline 2 & $\begin{array}{l}\text { Kemampuan memberi kesempatan klien } \\
\text { untuk berbicara }\end{array}$ & 22 & 100,00 \\
\hline 3. & $\begin{array}{l}\text { Kemampuan menjawab setiap } \\
\text { pertanyaan dengan sabar dan penuh } \\
\text { perhatian }\end{array}$ & 22 & 100,00 \\
\hline 4 & $\begin{array}{l}\text { Kemampuan untuk membicarakan hal-hal } \\
\text { yang bersifat tabu secara sopan }\end{array}$ & 22 & 100,00 \\
\hline 5. & $\begin{array}{l}\text { Kemampuan mempercayai semua } \\
\text { informasi yang diberikan klien serta } \\
\text { melakukan kajian kebenarannya }\end{array}$ & 16 & 72,73 \\
\hline 6. & $\begin{array}{l}\text { Kemampuan membantu klien } \\
\text { mengidentifikasi masalah dan cara-cara } \\
\text { penyelesaiannya }\end{array}$ & 16 & 72,73 \\
\hline 7. & $\begin{array}{l}\text { Kemampuan membantu klien untuk } \\
\text { mengkaji konsekwensi upaya } \\
\text { penyelesaian masalah }\end{array}$ & 22 & 100,00 \\
\hline \multirow[t]{2}{*}{8.} & $\begin{array}{l}\text { Kemampuan membantu klien untuk } \\
\text { memilih serta menetapkan keputusan } \\
\text { yang tepat dan mantap bagi dirinya } \\
\text { sendiri }\end{array}$ & 19 & 86,36 \\
\hline & $\begin{array}{l}\text { Rata-Rata Perencanaan, Pengambilan } \\
\text { Keputusan Penyelesaian Masalah }\end{array}$ & & 91,48 \\
\hline
\end{tabular}

Berdasarkan Tabel 4.7 tersebut di atas dapat diketahui bahwa Evaluasi dengan metoda penilaian diri oleh Bidan dalam Komunikasi Interpersonal dan Konseling dalam Pelayanan Antenatal Care pada Pada Perencanaan, Pengambilan Keputusan Penyelesaian Masalah di Puskesmas Kalitidu Kabupaten Bojonegoro adalah baik (rata-rata 91,48\%).

d). Penilaian Diri oleh Bidan dalam Kemampuan Komunikasi Interpersonal dan Konseling Pada Pelayanan Antenatal Care Terhadap Langkah Selanjutnya.

Penilaian Diri oleh Bidan dalam Kemampuan Komunikasi Interpersonal dan Konseling Pada Pelayanan Antenatal Care Terhadap Langkah Selanjutnya seperti tercantum pada Tabel 4.8 di bawah ini. 
Tabel 4.8 Gambaran Penilaian Diri oleh Bidan dalam Kemampuan Komunikasi Interpersonal dan Konseling Pada Pelayanan Antenatal Care Terhadap Langkah Selanjutnya Wilayah Puskesmas Kalitidu Kabupaten Bojonegoro, September 2021

\begin{tabular}{|c|c|c|c|}
\hline \multirow[t]{2}{*}{ No } & \multirow[t]{2}{*}{ Area Kompetensi oleh Bidan } & \multicolumn{2}{|c|}{$\begin{array}{c}\text { Penilaian Diri oleh } \\
\text { Bidan Di Puskesmas } \\
\text { Kalitidu } \\
n=22\end{array}$} \\
\hline & & $\begin{array}{c}\text { Ya } \\
\text { (Frek) }\end{array}$ & $\%$ \\
\hline IV. & LANGKAH SELANJUTNYA & & \\
\hline 1. & $\begin{array}{l}\text { Kemampuan untuk mengemukakan } \\
\text { kesimpulan serta mengulang keputusan } \\
\text { yang telah ditetapkan oleh klien }\end{array}$ & 13 & 59,09 \\
\hline 2. & $\begin{array}{l}\text { Kemampuan untuk mengkonformasikan } \\
\text { setiap keputusan atau pilihan klien, serta } \\
\text { memeriksa kembali kesepakatan hasil } \\
\text { Kip\&K pada saat itu }\end{array}$ & 16 & 72,73 \\
\hline 3. & $\begin{array}{l}\text { Kemampuan untuk menunjukkan sumber- } \\
\text { sumber dukungan lain atau rujukkan lain } \\
\text { yang dapat memberikan bantuan pada } \\
\text { klien lebih mendalam lagi. }\end{array}$ & 22 & 100,00 \\
\hline 4. & $\begin{array}{l}\text { Kemampuan untuk mendorong klien } \\
\text { melakukan kunjungan ulang }\end{array}$ & 22 & 100,00 \\
\hline 5. & $\begin{array}{l}\text { Kemampuan untuk mengucapkan } \\
\text { terimakasih pada klien atas kedatangannya } \\
\text { atau penerimaannya }\end{array}$ & 22 & 100,00 \\
\hline 6. & $\begin{array}{l}\text { Kemampuan untuk membuat catatan } \\
\text { tentang hal-hal penting dalam kegiatan } \\
\text { KIP\&K yang masih perlu tindak lanjut } \\
\text { melalui pertemuan berikutnya. }\end{array}$ & 16 & 72,73 \\
\hline
\end{tabular}

Keterangan : Nilai baik (>80\%), cukup (64\%-80\%), kurang (<64\%)

Berdasarkan Tabel 4.8 tersebut di atas dapat diketahui bahwa Evaluasi dengan metoda penilaian diri oleh Bidan dalam Komunikasi Interpersonal dan Konseling dalam Pelayanan Antenatal Care pada Langkah selanjutnya di Puskesmas Kalitidu Kabupaten Bojonegoro adalah baik (rata-rata 84.09\%).

2. Metoda Penilaian oleh Ibu Hamil Terhadap Pemenuhan Hak Ibu Hamil Yang Diberikan Oleh Bidan Sesudah Mendapat Pelatihan KIP/K

a. Penilaian Ibu Hamil Terhadap Pemenuhan Informasi

Penilaian pemenuhan hak ibu hamil terhadap informasi yang diberikan oleh Bidan di Puskesmas Kalitidu Kab. Bojonegoro dapat dilihat pada Tabel 4.9 di bawah ini. 
Tabel 4.9 Penilaian oleh Ibu Hamil terhadap Pemenuhan Hak Ibu Hamil tentang Informasi yang Diberikan Bidan, Sesudah Mendapat Pelatihan KIP/K di Puskesmas Kalitidu Kab. Bojonegoro, September 2021

\begin{tabular}{|c|c|c|c|}
\hline \multirow[t]{2}{*}{ No } & \multirow{2}{*}{$\begin{array}{l}\text { Pemenuhan hak ibu hamil } \\
\text { terhadap informasi yang } \\
\text { diberikan oleh Bidan }\end{array}$} & \multicolumn{2}{|c|}{$\begin{array}{l}\text { Penilaian oleh Ibu Hamil } \\
\text { terhadap Bidan setelah mendapat } \\
\text { Pelatihan KIP/K }\end{array}$} \\
\hline & & Frek & $\%$ \\
\hline 1 & Baik (> 80\%) & 110 & 100,00 \\
\hline 2 & Cukup baik (64\% -80\%) & - & - \\
\hline 3 & Kurang baik $(<64 \%)$ & - & - \\
\hline & Jumlah & 110 & 100,00 \\
\hline
\end{tabular}

Berdasarkan Tabel 4.9 tersebut di atas dapat diketahui bahwa di Puskesmas Kalitidu Kabupaten Bojonegoro $100 \%$ ibu hamil menyatakan pemenuhan haknya terhadap informasi baik.

\section{b. Penilaian Ibu Hamil Terhadap Pemenuhan Keterjangkauan Layanan}

Penilaian pemenuhan hak ibu hamil terhadap keterjangkauan pelayanan yang diberikan oleh Bidan di Puskesmas Kalitidu Kab. Bojonegoro dapat dilihat pada Tabel 4.10 di bawah ini.

Tabel 4.10 Penilaian oleh Ibu Hamil terhadap Pemenuhan Hak Ibu Hamil tentang Keterjangkauan Layanan yang Diberikan oleh Bidan Sesudah Mendapat Pelatihan KIP\&K di Puskesmas Kalitidu Kab. Bojonegoro, September 2021

\begin{tabular}{llrrr}
\hline No & $\begin{array}{c}\text { Pemenuhan hak ibu hamil terhadap } \\
\text { keterjangkauan layanan }\end{array}$ & \multicolumn{2}{c}{$\begin{array}{c}\text { Penilaian oleh Ibu Hamil } \\
\text { terhadap Bidan setelah } \\
\text { mendapat Pelatihan KIP/K } \\
\text { Frek }\end{array}$} \\
\hline 1 & Baik $(>80 \%)$ & 44 & 40,00 \\
2 & Cukup baik $(64 \%-80 \%)$ & 66 & 60,00 \\
3 & Kurang baik $(<64 \%)$ & 0 & - \\
\hline & & 110 & 100,00 \\
\hline
\end{tabular}

Berdasarkan Tabel 4.10 tersebut di atas dapat diketahui bahwa di Puskesmas Kalitidu $60 \%$ ibu hamil menyatakan pemenuhan haknya cukup baik dan $40 \%$ ibu hamil menyatakan pemenuhan haknya baik.

\section{c. Penilaian Ibu Hamil terhadap Pemenuhan Informed Choice}

Penilaian pemenuhan hak ibu hamil terhadap Informed Choice yang diberikan oleh Bidan di Puskesmas Kalitidu Kab. Bojonegoro dapat dilihat pada Tabel 4.11 di bawah ini.

Tabel 4.11 Penilaian oleh Ibu Hamil terhadap Pemenuhan Hak Ibu Hamil tentang Informed Choice yang Diberikan oleh Bidan Sesudah Mendapat Pelatihan KIP/K di Puskesmas Kalitidu Kab. Bojonegoro, September 2021 


\begin{tabular}{llrr}
\hline No & $\begin{array}{c}\text { Pemenuhan hak ibu hamil terhadap } \\
\text { Informed Choice }\end{array}$ & \multicolumn{2}{c}{$\begin{array}{c}\text { Penilaian oleh Ibu Hamil } \\
\text { terhadap Bidan setelah } \\
\text { mendapat Pelatihan KIP\&K } \\
\text { Frek }\end{array}$} \\
\hline 1 & Baik $(>80 \%)$ & 107 & 97,27 \\
2 & Cukup baik $(64 \%-80 \%)$ & 3 & 2,73 \\
3 & Kurang baik $(<64 \%)$ & 0 & - \\
\hline & & 110 & 100,00 \\
\hline
\end{tabular}

Berdasarkan Tabel 4.11 tersebut di atas dapat diketahui bahwa di Puskesmas Kalitidu 97,27\% ibu hamil menyatakan pemenuhan haknya terhadap Informed Choice baik

\section{d. Penilaian Ibu Hamil terhadap Pemenuhan Layanan Yang Aman}

Penilaian pemenuhan hak ibu hamil terhadap Layanan yang aman diberikan oleh Bidan di Puskesmas Kalitidu Kab. Bojonegoro dapat dilihat pada Tabel 4.12 di bawah ini.

Tabel 4.12 Penilaian oleh Ibu Hamil terhadap Pemenuhan Hak Ibu Hamil tentang Layanan Yang Aman yang Diberikan oleh Bidan Sesudah Mendapat Pelatihan KIP/K di Puskesmas Kalitidu Kab. Bojonegoro, September 2021

\begin{tabular}{|c|c|c|c|}
\hline \multirow[t]{2}{*}{ No } & \multirow[t]{2}{*}{$\begin{array}{c}\text { Pemenuhan hak ibu hamil terhadap } \\
\text { Layanan yang aman }\end{array}$} & \multicolumn{2}{|c|}{$\begin{array}{l}\text { Penilaian oleh Ibu Hamil } \\
\text { terhadap Bidan setelah } \\
\text { mendapat Pelatihan KIP/K }\end{array}$} \\
\hline & & Frek & $\%$ \\
\hline 1 & Baik (> 80\%) & 105 & 95,45 \\
\hline 2 & Cukup baik (64\% -80\%) & 5 & 4,55 \\
\hline 3 & Kurang baik $(<64 \%)$ & 0 & 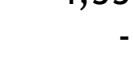 \\
\hline & Jumlah & 110 & 100,00 \\
\hline
\end{tabular}

Berdasarkan Tabel 4,12 tersebut di atas dapat diketahui bahwa di Puskesmas Kalitidu 95,45\% ibu hamil menyatakan pemenuhan haknya terhadap Layanan yang aman baik.

\subsection{Penilaian Ibu Hamil Terhadap Pemenuhan Privasi dan Kerahasiaan Pelayanan}

Penilaian pemenuhan hak ibu hamil terhadap Privasi dan Kerahasiaan yang diberikan oleh Bidan di Puskesmas Kalitidu Kab. Bojonegoro dapat dilihat pada Tabel 4.13 di bawah ini.

Tabel 4.13 Penilaian oleh Ibu Hamil terhadap Pemenuhan Hak Ibu Hamil tentang Privasi dan Kerahasiaan Pelayanan yang Diberikan oleh Bidan Sesudah Mendapat Pelatihan KIP\&K di Puskesmas Kalitidu Kab. Bojonegoro, September 2021 


\begin{tabular}{llrr}
\hline No & $\begin{array}{c}\text { Pemenuhan hak ibu hamil terhadap } \\
\text { Privasi dan Kerahasiaan Layanan }\end{array}$ & \multicolumn{2}{c}{$\begin{array}{c}\text { Penilaian oleh Ibu Hamil } \\
\text { terhadap Bidan setelah } \\
\text { mendapat Pelatihan KIP\&K } \\
\text { Frek }\end{array}$} \\
\hline 1 & Baik $(>80 \%)$ & 88 & 80,00 \\
2 & Cukup baik $(64 \%-80 \%)$ & 22 & 20,00 \\
3 & Kurang baik $(<64 \%)$ & 0 & - \\
\hline & & 110 & 100,00 \\
\hline
\end{tabular}

Berdasarkan Tabel 4.13 tersebut di atas dapat diketahui bahwa di Puskesmas Kalitidu $80 \%$ ibu hamil menyatakan pemenuhan haknya terhadap privasi dan kerahasiaan baik.

2.5 Penilaian Ibu Hamil Terhadap Pemenuhan Perlakuan Sopan, Ramah, Layanan yang Nyaman

Penilaian pemenuhan hak ibu hamil terhadap Privasi dan Kerahasiaan Layanan yang diberikan oleh Bidan di Puskesmas Kalitidu Kab. Bojonegoro dapat dilihat pada Tabel 4.14 di bawah ini.

Tabel 4.14 Penilaian oleh Ibu Hamil terhadap Pemenuhan Hak Ibu Hamil tentang Perlakuan Sopan, Ramah, Layanan yang Nyaman yang Diberikan oleh Bidan Sesudah Mendapat Pelatihan KIP\&K di Puskesmas Kalitidu Kab. Bojonegoro, September 2021

\begin{tabular}{llrr}
\hline No & $\begin{array}{c}\text { Pemenuhan hak ibu hamil terhadap } \\
\text { Perlakuan Sopan, Ramah, Layanan } \\
\text { Yang Nyaman }\end{array}$ & $\begin{array}{c}\text { Penilaian oleh Ibu Hamil } \\
\text { terhadap Bidan setelah } \\
\text { mendapat Pelatihan KIP/K } \\
\text { Frek }\end{array}$ \\
\hline 1 & Baik $(>80 \%)$ & 96 & 87,27 \\
2 & Cukup baik $(64 \%-80 \%)$ & 14 & 12,73 \\
3 & Kurang baik $(<64 \%)$ & 0 & - \\
\hline & & 110 & 100,00 \\
\hline
\end{tabular}

Berdasarkan Tabel 4.14 tersebut di atas dapat diketahui bahwa di Puskesmas Kalitidu $87,27 \%$ ibu hamil menyatakan pemenuhan haknya terhadap Perlakuan Sopan, Ramah, Layanan Yang Nyaman adalah baik.

\subsection{Penilaian Ibu Hamil terhadap Pemenuhan Kelangsungan Pelayanan}

Penilaian pemenuhan hak ibu hamil terhadap kelangsungan pelayanan yang diberikan oleh Bidan di Puskesmas Kalitidu Kab. Bojonegoro dapat dilihat pada Tabel 4.15 di bawah ini.

Tabel 4.15 Penilaian oleh Ibu Hamil terhadap Pemenuhan Hak Ibu Hamil tentang Kelangsungan Pelayanan yang Diberikan oleh Bidan Sesudah Mendapat Pelatihan KIP/K di Puskesmas Kalitidu Kab. Bojonegoro, September 2021 


\begin{tabular}{|c|c|c|c|}
\hline No & $\begin{array}{c}\text { Pemenuhan hak ibu hamil terhadap } \\
\text { kelangsungan pelayanan }\end{array}$ & \multicolumn{2}{|c|}{$\begin{array}{l}\text { Penilaian oleh Ibu Hamil } \\
\text { terhadap Bidan setelah } \\
\text { mendapat Pelatihan KIP/K }\end{array}$} \\
\hline 1 & Baik (> 80\%) & 94 & 85,45 \\
\hline 2 & Cukup baik (64\% -80\%) & 16 & 14,55 \\
\hline \multirow[t]{2}{*}{3} & Kurang baik $(<64 \%)$ & 0 & - \\
\hline & Jumlah & 110 & 100,00 \\
\hline
\end{tabular}

\section{KESIMPULAN}

Pelatihan Bidan tentang Komunikasi Interpersonal dan Konseling (KIP/K) dalam upaya peningkatan kualitas ANC dilakukan di Puskesmas Kalitidu menunjukkan bahwa terdapat peningkatan pengetahuan bidan $42,73 \%$, dan nilai sangat baik $100 \%$ yang diperoleh dari kemajuan hasil post test dibandingkat pre test. Keterampilan KIP/K nilainya sangat baik $86,36 \%$, menandatangani komitmen dalam mensukseskan kegiatan KIP/K dalam peningkatan kualitas ANC, Hasil monitoring dan evaluasi setelah mengikuti pelatihan dengan metode daftar tilik penilaian oleh diri sendiri dan penilaian oleh ibu hamil, hasilnya baik rata-rata nilainya $>80 \%$.

\section{DAFTAR PUSTAKA}

Febriati, L. D., \& Novika, A. G. (2021). Pelaksanaan Komunikasi Interpersonal atau Konseling (KIP/K) Oleh Bidan Pada Asuhan Antenatal Care. Jurnal Kebidanan Indonesia, 12(1). https: //doi.org/10.36419/jki.v12i1.433

Handajani, S. R. (2016). Komunikasi Dalam Praktik Kebidanan. http://bppsdmk.kemkes.go.id/pusdiksdmk/wpcontent/uploads/2017/08/Komunikasi-dalam-Praktik-Kebidanan.pdf

Kabupaten Bojonegoro. (2017). Profil Kesehatan Kabupaten Bojonegoro. Kabupaten Bojonegoro. (2018). Profil Kesehatan Kabupaten Bojonegoro. Kabupaten Bojonegoro. (2019). Profil Kesehatan Kabupaten Bojonegoro. Kemenkes RI. (2014). Infodatin-Ibu. Kemenkes RI, 1.

Pantiawati, I. (2010). Bayi dengan Berat Badan Lahir Rendah (BBLR).

Puskesmas Kalitidu. (2018). Profil Kesehatan Puskesmas Kalitidu.

Puskesmas Kalitidu. (2019). Profil Kesehatan Puskesmas Kalitidu.

Sulistiyanti, A., \& Sunarti. (2015). Kajian Pelaksanaan Antenatal Care Oleh Bidan di Wilayah Kerja Puskesmas Masaran Sragen. 5. https://ojs.udb.ac.id/index.php/infokes/article/download/63/63

Sunarni, N., Judistiani, T. D., Hinduan, Z. R., Sukandar, H., Madjid, T. H., \& Setyono, I. L. (2016). Hubungan Keterampilan Komunikasi Interpersonal dan Konseling oleh Mahasiswa Kebidanan dengan Kepuasan Klien di Bidan Praktik Mandiri. In 40 | IJEMC (Vol. 3, Issue 2). 